\title{
Camilla Bjørke
}

Høgskolelektor, Avd. for økonomi, språk og samfunnsfag, Høgskolen $i$ Østfold

\section{Berit Grønn}

Høgskolelektor, Avd. for økonomi, språk og samfunnsfag, Høgskolen $i$ Østfold

\section{Fremmedspråk på barnetrinnet - quo vadis?}

\section{Sammendrag}

Stortingsmelding nr. 30 (2003-2004) Kultur for laring (2004) åpner for at fremmedspråk kan tilbys på barnetrinnet. Europarådet og EU har lenge anbefalt flerspråklighet og tidlig språklcering, noe som også er en realitet i flere europeiske land. I Norge har det derfor vœrt gjennomført to statlig initierte forsøk med fremmedspråk på barnetrinnet (2005-2007 og 2010-2012). Evalueringene av begge forsøkene har vcert positive. Per i dag foreligger likevel ingen offisielle planer for vurdering av en permanent innføring, noe som var hensikten med forsøkene. Som språkdidaktikere og etterutdannere i forbindelse med "Forsøk med fremmedspråk på barnetrinnet"(2010-2012) foretok vi på slutten av forsøksperioden en liten undersøkelse av den muntlige språkkompetansen til noen av de deltakende elevene. Fordi lcereplanen i forsøket hadde et spesielt fokus på praktisk tilnærming $i$ en kommunikativ språkundervisning, var vi spesielt interesserte i hvilke samtale- og lytteferdigheter elevene hadde utviklet. Dette undersøkte vi blant annet ved hjelp av spontane samtaler på målspråket og intervjuer på norsk om elevenes erfaringer rundt språk og språklcering. Undersøkelsen vår kan betraktes som et supplement til foreliggende følgeforskning. Med denne artikkelen ønsker vi å bidra til å stake ut en didaktisk kurs for framtiden. Dette gjelder ikke bare for praktiserende språklærere på barnetrinnet, men også for kommende etter- og videreutdannere på dette feltet. Vi vil skape en faglig diskusjon rundt hvilke elementer man i framtiden bør satse på innen fremmedspråkopplcering på barnetrinnet.

\section{Bakgrunn}

Fremmedspråkfaget har fram til for ti år siden først og fremst vært knyttet til ungdomsskolen og videregående skole. Et veiskille oppstod imidlertid med Stortingsmelding nr. 30 (2003-2004) som på bakgrunn av positive forskningsresultater og lignende europeiske tendenser ga klare signaler til skoler og lærere at de som ville det og hadde nødvendig kompetanse, kunne starte opp med fremmedspråk på barnetrinnet. På bakgrunn av de erfaringene man etter hvert 
ville kunne høste, skulle departementet vurdere virkningen av en tidlig språklæring og på sikt vurdere om den skulle gjøres mer permanent (St. meld. nr. 30 (2003-2004), s. 48).

Ti år er gått, og fremmedspråk på barnetrinnet er ennå ingen realitet for alle elever. Til tross for muligheten til utvidelse av opplæringstilbudet har det på nasjonal basis vært relativt få skoler som har tilbudt fremmedspråk på barnetrinnet (Speitz, 2012, s. 11). Noen kommuner har likevel vist vilje og evne til satsing; i for eksempel Oslo er det per i dag 50 skoler som tilbyr fremmedspråk på 5.-7. trinn (Oslo kommune, Utdanningsetaten, 2014). Dette henger sammen med at kommunen har som uttalt mål at elevenes kunnskaper i fremmedspråk skal styrkes (op.cit.).

\section{Utprøving av fremmedspråk på barnetrinnet i statlig regi}

I perioden 2005-2012 ble det gjennomført to statlig initierte forsøk med fremmedspråk på barnetrinnet. Det daværende Utdannings- og forskningsdepartementet ga i juni 2005 ut strategiplanen Språk åpner dører som hadde som målsetning å styrke fremmedspråkfagene i grunnopplæringen (Utdanningsog forskningsdepartementet, 2005). Ett av de konkrete tiltakene for denne styrkingen var nettopp å igangsette forsøk med fremmedspråk på barnetrinnet. Med utgangspunkt i Stortingsmelding nr. 30, som klart uttrykte departementets positive syn på tidlig språkopplæring, og ovennevnte strategiplan inviterte Utdanningsdirektoratet tolv skoler til å være med på «Forsøk med tidlig start av 2. fremmedspråk» (heretter kalt TS). Dette første forsøket foregikk fra 2005 til 2007 og inkluderte veiledning og følgeforskning. De deltakende skolene var frie til å avgjøre timetall og hvilke språk (fransk, spansk og tysk) som skulle tilbys på hvilket trinn. Det ble heller ikke stilt krav til lærernes formelle kompetanse i det språket de skulle undervise i. En viktig føring var at språkundervisningen skulle ha praktisk tilncerming, noe som gjenspeilet Stortingsmeldingens intensjoner. Telemarksforsking-Notodden fikk oppdraget med følgeforskningen og leverte to delrapporter mens forsøket pågikk i tillegg til en sluttrapport (Speitz, Simonsen \& Streitlien, 2007). På grunnlag av de positive erfaringene med TS konkluderte Speitz m.fl. (2007, s. 50) med at en tidligere start med fremmedspråk kan anbefales.

I Stortingsmelding nr. 23 (2007-2008) Språk bygger broer (2008) tok Kunnskapsdepartementet utgangspunkt i TS sine positive erfaringer og ville videreføre utprøving av fremmedspråkopplæring på barnetrinnet. På oppdrag fra departementet satte dermed Utdanningsdirektoratet i gang det toårige forsøket «Forsøk med fremmedspråk på 6. og 7. trinn» (heretter kalt FFB) høsten 2010. Målsetningen var å høste bredere erfaring med fremmedspråkopplæring på disse trinnene, noe som igjen kunne gi grunnlag for vurdering ved en eventuell framtidig timetallsutvidelse. ”Faget skal legge et grunnlag for og motivere til 
videre fremmedspråklæring, være aktivitetsrettet og bidra til positive holdninger til flerspråklighet” (Fremmedspråksenteret, 2014).

Forsøket omfattet denne gangen hele 74 skoler med til sammen rundt 100 elevgrupper. Hele landet var representert, og FFB ble gjennomført med gjennomsnittlig to undervisningstimer (à $60 \mathrm{~min}$.) per uke på 6. og 7. trinn skoleårene 2010-2011 og 2011-2012. En egen læreplan (Utdanningsdirektoratet, 2010) gjeldende for perioden ble lagt til grunn for forsøket: Læreplan for fors $\varnothing k$ med fremmedspråk på barnetrinnet (heretter kalt forsøksplanen). Skolene ble tilbudt faglig støtte i forsøksperioden, og det ble utviklet et desentralisert kompetanse-hevingstilbud i fremmedspråk for lærerne. Fagmiljøene ved Høgskolen i Østfold (HiØ) og Norges teknisk-naturvitenskapelige universitet (NTNU) skulle tilby og organisere etterutdanningskurset. Kurset fikk en egen emnebeskrivelse og var basert på åtte samlinger à to dager. Emnebeskrivelsen la opp til at deltakerne primært skulle få økt kompetanse i fagdidaktikk, men de skulle også videre-utvikle sin egen språklige, kulturelle og kommunikative kompetanse.

Det som hadde vist seg å munne ut i en todelt organisering av språktilbudet i TS (Speitz m.fl. 2007), ble i FFB tilbudt fra oppstarten; for den toårige forsøksperioden måtte elevgruppene velge enten introduksjonsmodellen, der de fikk flere smakebiter av ulike språk, eller progresjonsmodellen, der de konsentrerte seg om ett språk. I tillegg til fransk, spansk og tysk ble språktilbudet utvidet til å gjelde også russisk og mandarin. Forsøket ble evaluert gjennom følgeforskning av SINTEF (Mordal, Aaslid, Lindemann \& Jensberg, 2013; Mordal, Jensberg \& Aaslid, 2011; Mordal, Lindemann \& Aaslid, 2012). Evalueringens hovedfunn var at alle aktørene var "meget fornøyde med forsøket og svært gjerne ønsker å fortsette med tiltaket” (Mordal m.fl. 2013, s. 19).

Begge forsøkene må altså karakteriseres som meget vellykkete; mange av lærerne har fått økt fagkompetanse, etter- og videreutdanningskompetanse er blitt etablert på to av landets utdanningsinstitusjoner og ikke minst finnes det mange fornøyde elever med gode språkkunnskaper. I sluttrapporten til FFB blir det påpekt at både elevene, lærerne og skoleeierne i forsøket mener fremmedspråk snarest må inn på barnetrinnet (Mordal et al., 2013, s. 19). Her blir det også antydet at det er sentralt å få til en oppfølgingsstudie av elevene i overgang til ungdomsskolen (op.cit.). Slik vil man få et enda større informasjonsgrunnlag omkring effekten av forsøket, noe som bør få beslutningstakere til å vurdere nasjonal innføring av fremmedspråk på barnetrinnet innen kort tid. I språklæringsøyemed er det uheldig at det går så mye som sju eller åtte år mellom innføring av engelsk på 1 . trinn og fremmedspråk på 8. trinn (Speitz m.fl. 2007, s. 12); det er dermed på tide at fremmedspråkundervisningen flyttes ned noen trinn, slik engelskfaget ble flyttet ned fra 3./4. trinn til 1. trinn i 1997. EU og Europarådet har lenge anbefalt flerspråklighet og tidlig språklæring (Europarådet, 1998, 2007), og det er en klar trend i andre europeiske land at fremmedspråkene introduseres på barnetrinnet 
(Speitz et al., 2007, s. 12). Forskning viser at elever støtter seg til tidligere erfaringer med språklæring når de lærer seg et nytt språk, hvilket er nok et argument for at fremmedspråkopplæringen bør introduseres på et tidligere stadium i skolen (Haukås \& Vold, 2012).

Som fagansatte i henholdsvis spansk og tysk ved HiØ (FFBsør) fikk vi gleden av å utvikle etterutdanningskurset i det nasjonale forsøket 2010-2012 sammen med språkdidaktikere tilknyttet NTNU (FFBnord). Ved HiØ ledet vi fellessamlingene, og sammen med to kolleger hadde vi hver våre workshops med lærerne inndelt etter språk. Innholdet i etterutdanningskurset var praksisnært, og i tråd med forsøksplanens føringer var kommunikativ språkundervisning et gjennomgående tema. Ulike undervisningsmetoder og arbeidsmåter for å styrke elevenes muntlige kompetanse utgjorde en vesentlig del av kurset. Målsetningen var at lærerne etter endt kurs skulle kunne planlegge, gjennomføre og reflektere over egen undervisning i lys av språklæringsteorier og kjennskap til tidligere erfaringer med fremmedspråkundervisning for den aktuelle aldersgruppen. Lærernes erfaringer fra egen undervisning var gjenstand for diskusjon og refleksjon på hver samling.

I kjølvannet av disse erfaringsutvekslingene klarte vi å danne oss et relativt godt bilde av hvordan lærerne operasjonaliserte forsøksplanens kompetansemål i egne klasserom. Vi ønsket imidlertid å få et enda nærmere innblikk i elevenes egne erfaringer med muntlige aktiviteter i språkopplæringen og deres muntlige kompetanse etter endt opplæring. Derfor foretok vi en undersøkelse av to elevgrupper der vi fokuserte på:

- hvilke lytte- og samtaleferdigheter elevene hadde utviklet i løpet av forsøksperioden

- i hvilke sammenhenger elevene fikk input på målspråket både $i$ og utenfor skolen

Undersøkelsen foregikk både på norsk og på målspråket, og den kan betraktes som et supplement til SINTEFs følgeforskning. Funnene fra vår undersøkelse kan bidra til å stake ut en videre didaktisk kurs for skoler som allerede tilbyr fremmedspråk på barnetrinnet og når faget forhåpentligvis innføres som et obligatorisk fag på barnetrinnet.

Nedenfor vil vi først redegjøre for bakgrunnen for og formålet med undersøkelsen. Deretter følger presiseringer av noen sentrale begreper vedrørende fremmedspråkopplæring hos barn, særlig med henblikk på lytting og snakking. Til slutt presenterer vi undersøkelsen og gjør oss noen refleksjoner rundt resultatene og framtidige didaktiske perspektiver. 


\section{Begrunnelse for og hensikt med undersøkelsen}

I juni 2012, like før forsøksperioden var over, besøkte vi to skoler som fulgte progresjonsmodellen. Siden muntlig kompetanse var sterkt vektlagt i forsøksplanen, ville vi finne ut i hvilken grad elevene hadde utviklet sin muntlige interaksjonskompetanse. Dette gjorde vi ved hjelp av intervju på norsk om elevenes språklige erfaringer, spontane samtale på målspråket og observasjon av to undervisningsøkter. SINTEF sin evaluering av FFB omfattet så langt vi kan se ikke spontane samtaler på målspråket som datamateriale, noe som derimot Telemarksforsking-Notodden delvis integrerte i sin evaluering av TS (Speitz m.fl. 2007, s. 44). Som fagdidaktikere kunne vi snakke med elevene på målspråket og dermed få bedre innsyn i hvordan elevene interagerte i muntlige samtalesituasjoner enn om vi kun hadde intervjuet dem på norsk rundt egen interaksjon på målspråket.

Undersøkelsen var liten; intervjuene og samtalene omfattet 22 elever fordelt på to skoler. Alle disse elevene hadde lært spansk. Den ene gruppen med spanskelever hadde fulgt undervisningen på en norsk skole i målspråksområdet, mens den andre hadde fulgt tilsvarende undervisning i Norge. En viktig grunn til at vi valgte ut akkurat disse to elevgruppene, var at deres respektive spansklærere hadde deltatt på etterutdanningskurset ved HiØ og sammen hadde utviklet en rekke undervisningsopplegg som de gjennomførte med hver sin elevgruppe. Noen av disse oppleggene innebar blant annet samarbeid mellom disse to elevgruppene via digital kommunikasjon. Elevene ved begge skolene hadde altså vært gjennom flere undervisningsopplegg som var ganske like når det gjaldt læringsmål og type aktiviteter, men i to ulike kontekster.

Når det gjelder skillet mellom spansk som andrespråk eller fremmedspråk ved skolen i Spania, vil vi hevde at det dreier seg om spansk som fremmedspråk. Skolen fulgte norske læreplaner og hadde norske lærere. I alle fag bortsett fra spansk og andre språkfag snakket elevene norsk. I friminuttene hørte vi kun norsk. De norske familiene oppholdt seg og jobbet ofte i norskspråklige miljøer, og vi fikk inntrykk av at mange betraktet spaniaoppholdet som midlertidig.

Vi hadde på forhånd utviklet en intervjuguide på norsk med åpne spørsmål, der vi tok utgangspunkt i emner og arbeidsmåter vi visste elevene hadde erfaring med, og vi la opp til impulsive samtaler i grupper. Dette ga rom til å spinne videre på relevante temaer som elevene brakte inn i samtalene, noe som er ett av kjennetegnene for spontan muntlig interaksjon (Bjørke \& Grønn, 2014). Slik fikk vi også skapt et gjensidig tillitsforhold mellom oss og elevene. Dette er særlig viktig når man bruker barn som informanter i en intervjuundersøkelse (Dalen, 2011, s. 38). I samtalene på norsk rundt elevenes språklæringserfaringer fikk elevene også vist sin metakognitive kompetanse; vi ba dem komme med konkrete eksempler på spansk når de selv brakte aktuelle temaer på banen. Hvis elevene fortalte om et tema de hadde dramatisert eller presentert muntlig, ba vi dem komme med eksempler på ord og setninger de hadde sagt. Dersom elevene 
refererte til samtaler de hadde hatt på målspråket, ba vi dem gjengi på spansk det de hadde sagt for å forstå eller gjøre seg forstått. Basert på det elevene fortalte på norsk om seg selv, klassen og skolen sin og de tanker de hadde gjort seg om egen språklæring, stilte fagdidaktiker improviserte spørsmål på spansk tilpasset elevenes språklige nivå. Ved å gripe tak i temaer elevene hadde vist de allerede var interesserte i og selv mente de behersket på spansk, forsøkte vi å skape en trygg atmosfære der elevene kunne utfolde seg muntlig på målspråket. På denne måten ville vi legge til rette for at de kunne vise bredden i sin kompetanse i spontan muntlig interaksjon.

I vår undersøkelse rettet vi oppmerksomheten mot elevenes hittil oppnådde muntlige kompetanse og deres muligheter for å videreutvikle sin språkkompetanse. I tillegg var vi opptatte av at språktilegnelse kan foregå på ulike arenaer: $\mathrm{i}$ et institusjonalisert læringsrom (skolen), og i dagliglivet ellers, avhengig av tilgang til språklig input og muligheter til å praktisere språket. I det følgende vil vi derfor ta for oss det vi mener er viktige begreper i et framtidsrettet språklæringsperspektiv, nemlig kompetanse for livslang læring, læringsarenaer og lyttetrening som en sentral del i muntlig interaksjon.

\section{Kompetansebegrepet og kompetanseutvikling hos store barn}

Kompetanse er et begrep man i dag opererer med innenfor en rekke områder som skole, utdanning og arbeidsliv. Læreplanen Kunnskapsløftet, heretter LK06 (Utdanningsdirektoratet, 2006), er sterkt orientert mot kompetanser, både generelt og i de enkelte fag. Den danske professoren i utdanningsforskning Knud Illeris (2012) fremhever Dominique S. Rychen \& Laura H. Salganiks (2003) definisjon av kompetansebegrepet som den mest brukte innen forskning og utdanning de senere årene. Begrepsdefinisjonen ble utviklet i tilknytning til OECDs mangeårige prosjekt DeSeCo (Definition and Selection of Competencies) og lyder slik (Rychen \& Salganik, 2003, s. 43):

En kompetence defineres som evnen til på en vellykket måde at forholde sig til komplekse krav i en bestemt sammenhæng, gennem en moblisering af psykosociale forudsætninger (herunder både kognitive og ikke-kognitive aspekter). Dette innebærer en krav-orienteret eller funktionel tilgang til definitionen av kompetencer. Der er især fokus på de resultater, individet opnår gennem en handling, et valg eller en adfærd med hensyn til de krav, der f.eks. er knyttet til en bestemt professionel position, social rolle, eller et personligt prosjekt.

Én av målsetningene med DeSeCo-prosjektet var "... å utvide indikatorene på læringsutbyttet i skolen” (Knain, 2005, s. 125). Stortingsmelding nr. 30 (20032004) støtter seg på DeSeCo-prosjektets definisjon av begrepet og beskriver kompetanse som "hva man gjør og får til i møte med utfordringer". Knain (2005, s. 126) viser at begrepet forstås og tolkes ulikt både i dagliglivet, på tvers 
av og innen samme fagmiljøer. I DeSeCos sluttrapport framheves tre kjernekompetanser: 1) handle autonomt og reflektert, 2) bruke verktøy interaktivt, 3) delta og fungere i heterogene sosiale grupper.

Illeris (2012, s. 40, 53) understreker at kompetansebegrepet har et handlingsperspektiv, er situasjonsrelatert og rommer både det man kan, det man umiddelbart er i stand til å gjøre, og det man har av relevante disposisjoner og potensialer. Disposisjoner er forankret i våre nedarvede gener og kan utvikles gjennom individets samspill med omgivelsene. Menneskets grunnleggende evne til å lære nye språk kan her nevnes som eksempel. Potensialer relateres til de oppgaver og handlinger man har gode forutsetninger for å kunne håndtere, og disse utgjør derfor en mulighet for videre utvikling og utfoldelse. Det allmenne kompetansebegrepet som er rådende i dag, er sterkt orientert mot det som kan måles, som kunnskaper og ferdigheter. Spørsmålet er om andre kompetanser, som kreativitet, fantasi, kombinasjonsevne og fleksibilitet, vil bli mer verdsatt i framtiden, særlig med tanke på å kunne håndtere ukjente og uforutsette situasjoner i et samfunn i rask endring.

Barns læring og utvikling av kompetanser finner sted i ulike sfærer og på ulike arenaer, både i og utenfor skolen. I skolen skjer det en systematisk og tilsiktet kompetanseutvikling gjennom det målrettede arbeidet som drives for at elevene skal oppfylle kompetansemålene i LK06. De kompetanser og ferdigheter barn tilegner seg i dagliglivet utenfor skolen, er ofte bredere, mer utilsiktet og ubevisst (Illeris, 2012, s. 117).

\section{Lytte- og samtaleferdigheter som muntlig kompetanse}

I forsøksplanen står utvikling av elevens kommunikative språkkompetanse sentralt. Det muntlige aspektet er tillagt stor vekt, og elevene skal ta språket aktivt i bruk fra første time:

Å lære et fremmedspråk dreier seg først og fremst om å bruke språket - å lese, lytte, snakke og skrive. Dette oppnås gjennom en aktivitetsrettet tilnærming og ved å ta språket i bruk i opplæringen fra første stund (Utdanningsdirektoratet, 2010). Kompetansemål for elever som følger progresjonsmodellen er blant annet å kunne "forstå og bruke en del vanlige ord og uttrykk knyttet til dagligliv, fritid og egne interesser" og "delta i dagligdagse samtalesituasjoner" (op.cit.). For å kunne delta i samtalesituasjoner er det imidlertid nødvendig å utvikle en rekke delkompetanser, deriblant å lytte og veksle i å føre ordet i samtaler.

Begrepene lytte, lytting og strategier for lytting forekommer eksplisitt flere steder i forsøksplanen, både i Formål med faget, i beskrivelsen av hovedområdet Språk og språklæring og i Grunnleggende ferdigheter i faget. Et kompetansemål innen hovedområdet Språk og språklcering lyder som følger: "kjenne til strategier for lesing, lytting og muntlig bruk av språket”. I tillegg forekommer 
ferdigheten lytting implisitt i flere av kompetansemålene i LK06, for eksempel "bruke ord og uttrykk for å få hjelp til å forstå og bli forstått” (op.cit.).

Elevene konstruerer egen kunnskap i samhandling med mennesker og omgivelsene rundt seg. Pinter (2006) fremhever den nære sammenhengen mellom lytting og snakking i språkinnlæring hos barn. Når barn lytter, og særlig når de blir oppslukt $\mathrm{i}$ lyttingen, plukker de opp chunks og grammatiske strukturer, som de lagrer og senere kan hente fram fra det mentale leksikonet når de skal produsere egne ytringer. I undervisningen bør derfor elevene eksponeres for mye lydlig input: "Young beginners should need to start with plenty of listening practice, and opportunities to listen to rich input will naturally lead to speaking tasks” (Pinter, 2006, s. 45). Nettopp derfor blir det så viktig at informasjon på målspråket gjentas gjennom ulike former for sosial samhandling med ulike deltakere og i ulike kontekster. I det sosiokulturelle læringsperspektivet fokuseres det på at elevens læring ikke bare forkommer i interaksjonen mellom lærer og elev, men også elevene imellom (Dysthe, 2001).

Når vi kan se samtalepartneren, er det lettere å tolke vedkommendes budskap fordi vi kan støtte oss på ikke-verbale (her: visuelle) signaler i tillegg til de verbale. I dagens samfunn brukes verbal kommunikasjon som ikke er fysisk ansikt-til-ansikt i stadig større grad i kombinasjon med visuell støtte, slik som Skype-samtaler, FaceTime og lignende. Muntlig interaksjon er en kompleks prosess der det er nødvendig med mange delkompetanser for at interaksjonen skal fungere. Dette er spesielt utfordrende på et fremmedspråk fordi man skal konsentrere seg om samhandlingsprosessen samtidig som man holder på å lære seg språket.

\section{Lytteferdigheter og forskning på lytting}

Det er mange års mellomrom mellom Paul Rankins og Kent Adelmanns studier av lyttingens rolle i kommunikasjonsprosessen, men begge kommer fram til omtrent samme resultat: I følge Rankin (1926) utgjør lytting en stor del av våre kommunikative aktiviteter i løpet av dagen, omtrent 45 \% (Rankin, 1926). Til forskjell fant han at snakking utgjør $30 \%$, lesing $16 \%$ og skriving $9 \%$. Det er lenge siden Rankins forskning, men Adelmanns (2009) senere forskning bekrefter det innbyrdes forholdet mellom de kommunikative aktivitetene.

Det er blitt drevet mest lytteforskning i USA og Australia, og da hovedsakelig fra et individualpsykologisk (kognitivt) perspektiv. I nordisk sammenheng kan Kent Adelmann (2009) og Hildegunn Otnes (2007) sin forskning innen området trekkes fram. I enkelte studier og framstillinger av muntlighet i norske klasserom behandles også temaet (Hertzberg \& Roe, 1999; Penne \& Hertzberg, 2008; Svenkerud, 2013; Svenkerud, Klette \& Hertzberg, 2012). Det gis en oversikt over forskning om muntlige ferdigheter generelt i den 
mer praktisk rettede boken Muntlig kompetanse (Børresen, Grimnes \& Svenkerud, 2012), hvor temaet lytting er viet et helt kapittel.

Lytteforskere skiller mellom å høre og å lytte. Mens å høre anses som en fysiologisk prosess, inngår det å lytte i en kommunikativ prosess: «... å lytte innebærer at man skaper mening og tar stilling til det som høres» (Børresen m.fl. 2012, s. 78). Lytting innbefatter både forståelse og respons og krever at mottakeren utfører flere operasjoner samtidig: Det verbale budskapet tolkes i lys av andre ikke-verbale signaler avsenderen sender ut. I dialogbasert kommunikasjon forventes det i tillegg at lytteren bekrefter om hun har forstått eller ikke, om hun ønsker å bryte inn og ta ordet eller om samtalepartneren kan fortsette å snakke. Adelmanns lytteforskning tar utgangspunkt i at lytting framfor alt er å betrakte som et sosialt og relasjonelt fenomen. Siden lytting ikke kan observeres direkte, baserer Adelmann seg på det han kaller rapportert lytting, det vil si den dokumenterbare responsen på det som sies (Adelmann, 2009, s. 76).

\section{Utvikling av lytteforståelse og samtaleferdigheter: forhandling om felles mening}

I språklige samhandlinger skapes mening gjennom at deltakerne samarbeider for å kunne nå et kommunikativt mål. I en samtale inntar deltakerne en dobbel funksjon, de både lytter og snakker. For at en samtale skal lykkes, må samtalepartnerne samhandle og koordinere sine handlinger på flere plan. En samtale kan betraktes som en kontinuerlig forhandlingsprosess, der «to samtalepartnere må bli enige fortløpende om hverandres ytringer i samtalen. Den som snakker, trenger en bekreftelse på at hun er blitt forstått slik hun intenderte, og den som lytter, trenger en bekreftelse på at hennes tolkning er akseptabel for taleren» (Svennevig, 2009, s. 84). For å forsikre seg om at de forstår hverandre, kan samtalepartnerne ta i bruk ulike samtalestrategier. Forståelse kan markeres gjennom tilbakemeldingssignaler, lytteren kan signalisere at hun følger med i samtalen og forstår ved å nikke og komme med små, bekreftende uttrykk. Taleren på sin side kan be om bekreftelse på at samtalepartneren følger med i samtalen ved å legge inn små ytringer av typen ikke sant? eller forstår $d u$ ?. Disse har en samtaleregulerende funksjon og er ikke ment som reelle spørsmål som trenger svar (Bjørke \& Grønn, 2014, s. 32). Av og til kan kommunikasjonsbrudd oppstå, og samtalen går helt eller delvis i stå. Reparasjonsstrategier kan da være oppklaringsspørsmål, modifisering av formuleringer gjennom forklaringer, repetisjon og parafrasering. Årsakene til kommunikasjonsbruddet kan være av grammatisk og/eller pragmatisk art. I fremmedspråk er det enda vanskeligere å gjenkjenne ord og uttrykk enn på morsmålet. Det samme gjelder tolkningen av intensjonen bak språkhandlingen på grunn av uskrevne regler for samtaleføring og ukjente, kontekstuelle faktorer. Svennevig (2009, s. 17) understreker at når vi deltar i språklige samhandlinger, utnytter vi både vår 
grammatiske og pragmatiske kompetanse. I all fremmedspråklæring blir det å kunne forhandle om mening derfor ekstra viktig på grunn av ovennevnte faktorer.

Innen forskning på fremmedspråk- og andrespråklæring er det foretatt få studier om barns bruk av forhandling om felles mening. En spansk undersøkelse om engelskelever i Spania viser at barna viste mer lytteforståelse dersom det var lagt inn rom for meningsforhandlinger underveis i en muntlig tekst enn om teksten kun var forenklet uten rom for meningsforhandlinger (Bazo Martínez \& Peñate Cabrera, 2002). I en annen undersøkelse (Oliver, 1998) fant man at barn mellom 8 og 13 år nyttiggjør seg meningsforhandlinger når de samhandler muntlig, ikke bare på eget morsmål, men også på et fremmedspråk. Barn i denne alderen bruker imidlertid forhandlingsstrategier på en annen måte og i annen grad enn voksne. Barna konsentrerer seg mer om å konstruere egne meningsytringer enn om å forsikre seg om at samtalepartneren forstår (op.cit.). Barn har mindre allmennkunnskap enn voksne, noe som gjør at de ikke kan ta i bruk gjettestrategier i like stor grad. Funnene i de to nevnte studiene innebærer at man i fremmedspråkundervisningen på barnetrinnet bør introdusere aktiviteter som innbefatter forhandling om felles mening gradvis og med omhu. Samtaler på målspråket bør omhandle kjente emner uten for mange tolkningsmuligheter. Slik unngår man at elevene må forholde seg til hyppige kommunikasjonsbrudd som de ikke har forutsetninger for å klare å reparere. Dette hadde vi i tankene da vi forberedte og gjennomførte undersøkelsen vår.

\section{Undersøkelsen}

Ved de to skolene vi besøkte i juni 2012 tilbød de kun spansk på barnetrinnet. Vi observerte først undervisningen i én dobbelttime i spansk. Deretter intervjuet vi elevene i grupper på tre eller fire, ti elever på den ene skolen og tolv på den andre. Hvert intervju varte cirka én time. Intervjuets siste del bestod som nevnt av spontane samtaler med elevene på spansk. Den ene skolen vi besøkte ligger i en liten kommune i et ruralt område i Norge, og vil heretter bli kalt Skole N. Den andre er en norsk skole i en liten by i Spania, heretter kalt Skole S. Skole N tilbyr undervisning fra 1.-10. trinn, mens Skole $S$ er en 1-13-skole.

Undervisningsøktene vi observerte på de to skolene, var basert på ulike temaer. Ved Skole N presenterte elevene en forberedt muntlig presentasjon av et drømmehus. Ved Skole S fikk vi som observatører bli med på et besøk til et gatemarked (rastro) i nærområdet. Der løste elevene oppgaver som var relaterte til handlesituasjoner. For å finne riktig informasjon måtte elevene samhandle muntlig med selgerne.

I elevintervjuene på norsk konsentrerte vi oss om noen hovedtemaer: 1) muntlige aktiviteter elevene hadde likt i spanskundervisningen, 2) lytting og samtaleferdigheter, herunder hvilke strategier elevene brukte for å forstå og 
gjøre seg forstått, 3) målspråksmøter utenom ordinær spanskundervisning (utilsiktet kompetanseutvikling). I utformingen av intervjuguiden baserte vi oss på teoretisk materiale innen fremmedspråklæring hos barn og bakgrunnsinformasjon vi hadde fått gjennom undervisningsopplegg lærerne presenterte på samlingene på etterutdanningskurset. Ett av oppleggene munnet ut $\mathrm{i}$ at de to elevgruppene ved de respektive skolene gjennomførte en Skypesamtale, der de intervjuet hverandre på spansk om hjemstedet sitt. Skole N fikk i tilknytning til et undervisningsopplegg besøk av en målspråktaler, David, som samtalte med elevene.

I de spontane samtalene på målspråket tok vi som tidligere nevnt utgangspunkt i temaer vi visste elevene hadde arbeidet med og var interesserte $\mathrm{i}$; dersom en elev spilte fotball, spurte vi hva de andre på laget het og så videre. Å transkribere muntlige intervjuer og samtaler innebærer en tolkningsprosess; man oversetter talespråket til skriftspråk, og i denne prosessen vil viktige aspekter i den muntlige diskursen gå tapt: "Transkripsjon er kort sagt svekkede, dekontekstualiserte gjengivelser av direkte intervjusamtaler” (Kvale \& Brinkmann, 2009, s. 187). I og med at intervjuformen var sterkt preget av spontanitet, vil vi derfor aldri kunne gjenskape helt og holdent det elevene sa, men vi har forsøkt så langt det er mulig å bevare meningsinnholdet.

\section{Resultater av undersøkelsen}

I gjennomgangen av undersøkelsen skiller vi mellom intervjuene på norsk om elevenes språklige erfaringer og de spontane samtalene på målspråket. Vi presenterer her utdrag fra undersøkelsen som er typiske for elevsvarene/responsene.

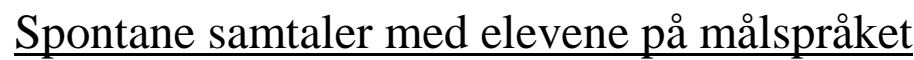

Fagdidaktiker og elevene samtalte om seg selv, familie, venner, kjæledyr, bo- og hjemsted og fritidsinteresser. Det inntrykket vi fikk av elevenes lytteforståelse, er basert på rapportert lytting (Adelmann, 2009), hvilket vil si at den responsen som elevene ga under samtalen kun er indikasjoner på det elevene forstod. Disse kan deles i den responsen elevene ga på spørsmål fra fagdidaktiker på den ene siden og den responsen elevene ga på hverandres ytringer under samtalen på den andre. Samtalene på målspråket ble verken spilt inn eller transkribert. Vi presenterer derfor hovedinntrykkene vi satt igjen med etter samtalene.

Elevene forstod enkle spørsmål fagdidaktiker stilte dem. Det virket som elevene hadde svart på tilsvarende spørsmål mange ganger før. De kunne svare nærmest på rams (formulas og chunks). Derfor valgte fagdidaktikeren å teste lytteforståelsen deres ytterligere ved å stille elevene oppfølgingsspørsmål innen samme temaer, men da med andre variabler. Elevene viste også her relativt god lytteforståelse selv om de var litt mer uforberedt. Når de ikke forstod, eller var 
usikre på hvordan de skulle formulere responsen, benyttet de hovedsakelig reparasjonsstrategier; de ba for eksempel om gjentakelse av spørsmålet (Repite, $¿$ ¿Puedes repetir, por favor?) eller spurte om enkeltords betydning eller oversettelse (¿Qué significa baloncesto?, ¿Qué es trening en español?). Når elevene selv hadde ordet, benyttet de så godt som ikke tilbakemeldingssignaler for å sjekke om de andre hadde forstått (Oliver, 1998).

Elevene besvarte som regel spørsmål med enkeltord og korte enkeltsetninger. Noen formulerte flere setninger etter hverandre, og noen få var tydelig opptatte av å ta i bruk en grammatisk struktur de hadde øvd på den siste uka, for eksempel verbalperifrasen ir $+a+$ infinitiv (for å uttrykke handlinger i framtid). Når det gjelder elevenes muntlige samhandling seg imellom, bet vi oss spesielt merke i én ting: Hvis en elev stoppet opp fordi hun ikke kjente til eller husket et ord, eller var usikker på formuleringen, skjøt medelevene inn nødvendige eller manglende ord eller setninger som en støttende gest.

\section{Elevintervjuene på norsk}

Med hensyn til hvilke muntlige aktiviteter elevene likte å gjøre i spansktimene, var det stor variasjon i svarene, og alle nevnte flere aktiviteter. Mange trakk fram det å forberede muntlige presentasjoner, finne bilder selv og finne fram til passende ord for å beskrive bildet. Flere nevnte at de likte å dramatisere og filmatisere eventyr, filme små sekvenser og lage fantasidialoger. A gjøre interaktive oppgaver på nett med lyd og talefunksjoner ble også hyppig nevnt. Elevene ved Skole $\mathrm{N}$ trakk fram besøk av målspråktaler eller andre spanskkyndige som ekstra stas. Mange elever likte også å høre på musikk og synge til $\mathrm{CD}$, men understreket at sangene ikke måtte være for barnslige. Spesielt fremhevet elevene det forberedende arbeidet i muntlig produksjon (prosjektarbeid og lignende), blant annet fordi det ga dem rom til å formulere læringsmål selv.

Videre uttrykte elevene at de følte seg trygge når lærer brukte målspråket i klasserommet og at de ikke ble satt ut av spill selv om de ikke forstod alt. Lyttestrategiene de rapporterte mest om, var bruk av forkunnskaper om ord og ords betydning og det å rette oppmerksomheten mot ord de kunne (top-downprocessing). Følgende elevuttalelse kan tjene som eksempel: «Det gjør ingenting om vi ikke forstår alt læreren sier på spansk. Vi forstår jo litt». Elevene ved Skole $\mathrm{N}$ mente selv at de i samtalen med morsmålstaleren David hadde anvendt meningsforhandling i større grad enn de vanligvis gjorde i spansktimene. De eksemplifiserte dette ved å gjengi ord og fraser de hadde brukt hvis de ikke forstod hva han sa (Repite, por favor, Despacio, No entiendo, Otra vez). De hadde også skjønt at David brukte synonymer og forenklinger når han oppfattet at de ikke hadde forstått helt.

I samtalen med målspråktaleren David og i Skype-samtalen på spansk (elevene ved begge skolene) fortalte elevene at de gikk så til de grader inn i rollen som samtalepartner at de glemte å ty til hjelpemidler de hadde 
tilgjengelig, som for eksempel støtteark med ord og setninger de selv hadde formulert på forhånd. I Skype-samtalen brukte elevene norsk i svært liten grad: "Vi stod i kø, og så snakket vi to og to med elever fra den andre skolen. Vi snakket mye spansk, nesten hele tiden. Av og til var det dårlig lyd, og vi skjønte ikke hva de andre sa, da snakket vi norsk".

Under intervjuene vi hadde med elevene, begynte enkelte å reflektere rundt forskjellen mellom reseptive og produktive ferdigheter og hvordan muntlig interaksjon kan virke gunstig på egen språklæringsprosess. De filosoferte blant annet rundt hvor mye mer de forstod enn de selv klarte å uttrykke på målspråket og at de ved å snakke med andre på spansk ble påminnet ord og ords betydning som de selv hadde glemt. De kom med eksempler på hvordan de utnyttet sine kunnskaper om chunks i egen muntlig produksjon: "Når vi skulle fortelle hva vi likte, så sa vi bare me gusta og så puttet vi på den tingen vi likte”.

Når det gjelder språklig input og praktisering av målspråket utenom skolen, den såkalt utilsiktede kompetanseutviklingen (Illeris, 2012), var det forskjeller mellom Skole $\mathrm{S}$ og Skole $\mathrm{N}$, men disse var ikke så vesentlige som vi i utgangspunktet trodde. Fire av elevene ved Skole $\mathrm{S}$ deltok i organiserte fritidsaktiviteter, som dans, ridning og fotball, der treneren eller instruktøren snakket spansk. Disse elevene kunne gjenta noen faste fraser treneren eller instruktøren pleide å si, men alle poengterte at i dans og idrett gjør man ofte bevegelser samtidig som man instruerer, og at de derfor også støttet seg mye på mimikk, gestikulering og bevegelser. To av elevene pleide å snakke spansk i handlesituasjoner. Blant elevene ved Skole $\mathrm{N}$ var det ingen som praktiserte språket i fritiden, og kun én hadde vært på ferie i et spansktalende land i løpet av perioden forsøket varte, og da hadde hun snakket litt i handlesituasjoner. I tillegg skilte elevene ved Skole S seg fra elevene ved skole $\mathrm{N}$ når det gjaldt å se på videosnutter med spansk tale på YouTube i fritiden. To av dem fortalte også at de spilte dataspill på spansk.

\section{Fremmedspråk på barnetrinnet - drøfting rundt framtidige perspektiver}

I vår undersøkelse fant vi at elevene følte seg trygge og selvsikre når de ble eksponert for målspråket i samtalesituasjoner. Vi fant også at de var på god vei i sin utvikling når det gjaldt $a ̊$ ta $\mathrm{i}$ bruk hensiktsmessige lytte- og samtalestrategier. Det var også tydelig at de benyttet seg av chunks når de ytret seg muntlig på målspråket. Samtidig uttrykte elevene ønske om å utvide sine kunnskaper om det grammatiske systemet for å lage mer komplekse formuleringer. Den ene eleven uttrykte det slik: "Jeg vil vite mer om hvordan jeg skal bøye verbet riktig, slik at det blir riktig person". Elevene var i en fase der de så at produksjon krever andre og mer inngående grammatikkunnskaper 
enn resepsjon: "... the psycholinguistic demands of composing messages force speakers to use syntactic processing to a much greater extent” (Ortega, 2009, s. 62). Elevenes samhandlingsmønstre i samtaler på målspråket viste at de brukte hverandre som læringsstillaser, en strategi de kan bygge videre på. Disse læringsstillasene kan ha overføringsverdi til andre fag og dagliglivet ellers og er et område vi trenger mer kunnskap om.

DeSeCo-prosjektet fremhevet som nevnt tre kjernekompetanser for framtiden, hvorav den første var "å handle autonomt og reflektert” (Knain, 2005, s. 132). I intervjuene fortalte flere elever at de likte å finne fram til ord og ords betydning på egen hånd i ordbøker på nett og i papirutgave og i andre nettkilder. Elevene likte med andre ord å ta kontroll over egen språklæringsprosess, skaffe seg oversikt over hvilke ord de trengte og å utforske språket. Elevene utviklet lingvistisk bevissthet og kompetanse i innhenting av relevant informasjon. På den måten opptrådte de autonomt og reflektert. Elevene likte også å formulere læringsmål selv; flere brukte begrepet lceringsmål aktivt, noe som tydet på at de var vant til å arbeide bevisst mot mål de hadde satt seg.

Med dagens teknologiske utvikling er det klart at elevene har økte muligheter til målspråksmøter gjennom bruk av digitale verktøy, for eksempel via nett. Digitale ferdigheter er en av de fem grunnleggende ferdighetene som er integrert i kompetansemålene i forsøksplanen. Digital kompetanse består av flere delkompetanser. Tyner (1998) skiller mellom tool literacies og literacy of representation. Det første begrepet omfatter instrumentelle ferdigheter og det andre refererer til medienes uttrykksformer og meningsskaping. Det er i sistnevnte betydning vi har brukt begrepet i og med at elevene hadde meningsfulle samtaler på målspråket ved hjelp av digitale verktøy.

Både på skolen og i fritiden kan elevene benytte digitale medier for å komme i kontakt med målspråket, for eksempel via Skype og chatting på Facebook. I utdanningsøyemed bruker Otnes begrepet relevans, som referer til at ”... man som lærer ser de digitale mediene i en faglig sammenheng og lar elevene bruke dem der det er faglig relevant” (Otnes, 2009, s. 14). Skype-samtalen mellom elevene vi intervjuet, kan tjene som et eksempel på bruk av et digitalt medium og faglig relevans. Mediet gjorde at spanskelever som befant seg på hver sin kant av Europa kunne samhandle muntlig. Denne form for læring knyttes opp mot et sosialkonstruktivistisk læringssyn der læring skjer mellom aktørene på nett (Grüters \& Langseth, 2009, s. 113). Lignende bruk av digitale medier brukes allerede en god del i engelsk- og fremmedspråkundervisningen, men kommer nok til å øke i tiden framover. I framtiden vil det derfor være interessant å undersøke i hvor stor grad og på hvilken måte elevene utnytter denne muligheten i egen språklæringsprosess. At elevene opptrer på flere ulike arenaer, vil muligens gjøre at den tilsiktede (på skolen) og utilsiktede (i fritiden) kompetanseutviklingen går over i og supplerer hverandre (Illeris, 2012).

Det er verdt å merke seg at selv om elevene ved Skole $\mathrm{S}$ hadde større språklig input enn elevene ved Skole $\mathrm{N}$, viste begge elevgruppene omtrent 
samme muntlige kompetanse. Enkelte forskere hevder at store mengder reseptiv eksponering av målspråket ikke automatisk fører til mer språklæring (Ortega, 2009, s. 60). Det er vanskelig å si noe om hvordan elevene ved Skole S utnyttet tilgangen til språklig input utenom skolen i egen språklæring. Det kan virke som elevene hørte mer enn de lyttet (se ovenfor). I for eksempel dataspill kan man i stor grad støtte seg på visuelle uttrykk og sjangerkunnskap uten å måtte feste seg særlig ved språket.

Som lærer kan man stimulere elevene til å bruke digitale verktøy for målspråksmøter i mye større grad enn praksis er i dag, både i og utenom skolen. Elevene vil da trenge veiledning i å vurdere kritisk og utnytte de mulighetene digitale medier gir. Økt bruk av digitale medier i fremmedspråklæringen fører til endringer i lærerrollen. Otnes poengterer at læreren ikke bare bør assimilere teknologien i eksisterende undervisningspraksiser, men la den danne utgangspunkt for nye praksiser (Otnes, 2009, s. 14). Dette medfører et enda større fokus på strategibruk. Undervisningsmetoder og arbeidsmåter i fag må være i takt med det moderne samfunnet vi lever i. Dette får følgelig konsekvenser for innholdet både i undervisningen i fremmedspråk og i utdanningen av lærere.

Globaliseringen og den teknologiske utviklingen gjør at man på barnetrinnet må være ekstra påpasselig for at eleven ikke overstimuleres og at hun får tid og rom til å prosessere og bearbeide informasjon. Pinter (2006, s. 45) viser til viktige suksessfaktorer som lærerens kjennskap til elevenes læreforutsetninger og et trygt læringsmiljø. Dette vurderer hun som avgjørende for å lykkes med fremmedspråk på barnetrinnet.

Den andre kjernekompetansen fremhevet i DeSeCo-prosjektet er å bruke verktøy interaktivt, som blant annet omfatter språk og konkrete ferdigheter som lese- og skriveferdigheter (Knain, 2005, s. 132). Den kommunikative språkkompetansen elevene tilegner seg er viktig for videreutvikling av nevnte kjernekompetanse. Det felles europeiske rammeverket for språk deler kommunikativ språkkompetanse i tre delkompetanser: 1) lingvistisk kompetanse, 2) pragmatisk kompetanse og 3) sosiolingvistisk kompetanse (Utdanningsdirektoratet, 2011). Elevene vi intervjuet, var i ferd med å utvikle kompetanser innen alle disse tre områdene, særlig med hensyn til pragmatisk kompetanse (utføre språkhandlinger). For å kunne møte framtidens utfordringer tror vi kreativ bruk av språket og det å kunne kombinere ulike uttrykksformer (auditive, visuelle og verbale) vil etterspørres enda mer enn i dag, og må derfor få større plass i språkundervisningen (jfr. elevenes fantasidialoger).

Vi mener det er behov for videre forskning innen områder som går ut på lærerens og elevens bruk av målspråket. Likeledes vil det være behov for forskning på elevenes lytting i klasserommet, både for å få nærmere kunnskap om elevenes bruk av strategier og hvordan strategiundervisningen foregår. Samtaler står veldig sentralt i hele Kunnskapsløftet, mens den essensielle bestanddelen i all samtale, nemlig lytting, er lite fremhevet i de ulike 
læreplanene for fag i LK06, med unntak av språkfagene og RLE-faget. Det kan imidlertid virke som utdanningsmyndighetene nå ønsker å rette større oppmerksomhet mot lytting; denne ferdigheten har fått en framtredende rolle i sentrale styringsdokumenter som Rammeverk for grunnleggende ferdigheter (Utdanningsdirektoratet, 2012) og i forsøksplanen (Utdanningsdirektoratet, 2010).

Elevens læringsutbytte etter å ha lært fremmedspråk på barnetrinnet bør kartlegges systematisk. Dette vil kunne gi grunnlag for videre planlegging og vurdering av hvordan fremmedspråkundervisningen bør drives i Norge i årene framover, blant annet med tanke på endringer av gjeldende opplæringsløp og læreplaner i fremmedspråk. Skal for eksempel opplæringen i fremmedspråk på ungdomstrinnet (8.-10. trinn) fortsatt kalles nivå I?

Det bør også være av nasjonal interesse å finne ut hvordan det har gått med elevene som har deltatt i de to statlig initierte forsøkene. Elever som deltok i FFB vil gå i 10. trinn skoleåret 2014/15. Utdanningsmyndighetene har hittil ikke presentert en plan for hvordan disse elevene skal følges opp. Det kan se ut som oppfølgingen av disse elevene er ganske tilfeldig. Om elevene har fått mulighet til å utnytte sitt læringspotensial helt og fullt etter to år med fremmedspråk på barnetrinnet, synes å avhenge av kommunens og/eller skolens profil og satsingsområde. Man kan også stille spørsmål om elevenes rettigheter til tilpasset opplæring blir godt nok ivaretatt. En av lærerne i undersøkelsen vår kunne informere om at elevgruppen hennes hadde søkt Fylkesmannen om å få ta eksamen på nivå 1 (Lcereplan for fremmedspråk i LK06) på slutten av 9. trinn, men fikk avslag, noe som kan virke demotiverende for videre språklæring.

Den tredje og siste kjernekompetansen DeSeCo-prosjektet trakk fram, handlet om "å delta og fungere i heterogene sosiale grupper”. Dette innebærer blant annet å utvikle sosial, kulturell og interkulturell kompetanse. I vår artikkel har vi knapt tatt for oss disse delkompetansene. Likevel kan resultatene fra undersøkelsen vår tyde på at elevenes oppnådde språk- og interaksjonskompetanse etter to år med fremmedspråk danner et godt utgangspunkt for å få et mer nyansert bilde av andres levemåter og kulturer. Jo flere år elevene får mulighet til å bygge opp sin språkkompetanse, desto flere dører vil åpnes for å kunne opparbeide seg ikke bare en kulturspesifikk kompetanse vedrørende det aktuelle målspråksområdet, men også en kulturgenerell kompetanse.

Gjennom undersøkelsen vår fikk vi bedre innsikt i hvilke muntlige ferdigheter elevene hadde utviklet, samt deres læringspotensial når det gjelder hvilken kompetanse elevene kan bygge videre på i språkopplæringen på ungdomstrinnet, i videregående skole og i et livslangt perspektiv. Vi fant også at elevene var utforskende i egen språklæringsprosess og at de hadde gjort seg noen erfaringer om hvordan digitale verktøy kan utnyttes for å lære seg språk, noe som økte deres metakognitive og lingvistiske bevissthet. Med utgangspunkt i forsøkene som er nevnt her, foreliggende rapporter og aktuell forskning er det mye som tyder på at en nasjonal innføring av fremmedspråk tidlig i opplæringen 
er gunstig for elevenes videre språklæring. Vår opparbeidede kompetanse som etterutdannere for lærerne i FFB og vår innsikt i noen av FFB-elevenes muntlige ferdigheter ved forsøkets slutt (jfr. undersøkelsen vår) gir oss et grunnlag for å kunne skissere hva som bør vektlegges i språkundervisningen på barnetrinnet i tiden framover. De viktigste bestanddelene i en framtidsrettet språkopplæring tidlig i opplæringsløpet er etter vårt syn å skape meningsfulle samtalesituasjoner på målspråket der elevene gis rom til å utforske språket på egen hånd. Samtidig bør det jobbes eksplisitt med lytte- og samtalestrategier slik at elevene kan utnytte disse til fulle i egen språklæringsprosess på ulike læringsarenaer.

Avslutningsvis etterlyser vi den planlagte vurderingen fra departementalt hold for framtidig permanent innføring. Slik situasjonen er i dag, er det tilfeldig hvilke elever som får tidlig opplæring i fremmedspråk avhengig av den enkelte skoles/kommunes satsing. Tiden er dermed moden for å få en avklaring om alle elever i Norge skal tilbys fremmedspråk på barnetrinnet eller om det fortsatt skal forbeholdes et fåtall. Dernest etterlyser vi oppfølging av de elevene som deltok i det nasjonale forsøket 2010-2012. Dette kan gi oss verdifull kunnskap om den langsiktige virkningen av tidlig språklæring.

\section{Referanser}

Adelmann, K. (2009). Konsten att lyssna: Didaktiskt lyssnande i skola och utbildning. Lund: Studentlitteratur.

Bazo Martínez, P. \& Péñate Cabrera, M. (2002). Input and interlanguage in the EFL classroom: A case study with primary school teachers. CAUCE Revista de Filología, Comunicación y sus Didácticas, 25, 459-474. Hentet fra http://cvc.cervantes.es/literatura/cauce/pdf/cauce25/cauce25_21.pdf

Bjørke, C. \& Grønn, B. (2014). Muntlige ferdigheter i språkfagene. I C. Bjørke, M. Dypedahl, \& G.-A. Myklevold (Red.), Fremmedspråksdidaktikk (s. 30-42). Oslo: Cappelen Damm Akademisk.

Børresen, B., Grimnes, L. N. F. \& Svenkerud, S. (2012). Muntlig kompetanse. Bergen: Fagbokforlaget.

Dalen, M. (2011). Intervju som forskningsmetode. Oslo: Universitetsforlaget.

Dysthe, O. (2001). Sosiokulturelle teoriperspektiv på kunnskap og læring. I O. Dysthe (Red.), Dialog, samspel og lering (s. 33-72). Oslo: Abstrakt forlag.

Europarådet. (1998). Recommendation No. R (98) 6. of the Committee of Ministers to Member States concerning Modern Languages. Hentet fra https://wcd.coe.int/com.instranet.InstraServlet?command=com.instranet.CmdBlobGet\&In stranetImage $=530647 \&$ SecMode $=1 \&$ DocId $=459522 \&$ Usage $=2$

Europarådet. (2007). From linguistic diversity to plurilingual education: Guide for the Development of Language Education Policies in Europe. Hentet fra http://www.coe.int/t/dg4/linguistic/Guide_niveau3_EN.asp\#TopOfPage

Fremmedspråksenteret. (2014). Fremmedspråk på barnetrinnet. Hentet fra http://www.fremmedspraksenteret.no/nor/fremmedspraksenteret/fremmedsprak-pabarnetrinnet-1

Grüters, R. \& Langseth, I. (2009). Å være digital i fremmedspråk. I H. Otnes (Red.), A være digital i alle fag (s. 105-125). Oslo: Universitetsforlaget. 
Haukås, Å. \& Vold, E. T. (2012). Internasjonale trender innen fremmedspråksdidaktisk forskning. Norsk pedagogisk tidsskrift, 96(05). Hentet fra

http://www.idunn.no/ts/npt/2012/05/internasjonale_trender_innen_fremmedspraaksdidakt isk_forskni

Hertzberg, F. \& Roe, A. (1999). Muntlig norsk. Oslo: Tano Aschehoug.

Illeris, K. (2012). Kompetence: hvad, hvorfor, hvordan? Frederiksberg: Samfundslitteratur.

Knain, E. (2005). Definering og valg av kompetanser - DeSeCo. Norsk pedagogisk tidsskrift, 89(01). Hentet fra

http://www.idunn.no/ts/npt/2005/01/definering_og_valg_av_kompetanser_-_deseco

Kvale, S. \& Brinkmann, S. (2009). Det kvalitative forskningsintervju. Oslo: Gyldendal Akademisk.

Mordal, S., Aaslid, B. E., Lindemann, B. \& Jensberg, H. (2013). To år med fremmedspråk erfaringer og betraktninger. Sluttrapport i evalueringen av forsøk med 2. fremmedspråk som felles fag på 6.-7. trinn i perioden 2010-2012. Trondheim: SINTEF.

Mordal, S., Jensberg, H. \& Aaslid, B. E. (2011). Evaluering av forsøk med 2. fremmedspråk på 6.-7. trinn, Delrapport 1. Trondheim: SINTEF.

Mordal, S., Lindemann, B. \& Aaslid, B. E. (2012). Evaluering av forsøk med 2. fremmedspråk på 6.-7. trinn, Delrapport 2. Trondheim: SINTEF.

Oliver, R. (1998). Negotiation of Meaning in Child Interactions. The Modern Language Journal, 82(3), 372-386. doi:10.1111/j.1540-4781.1998.tb01215.x

Ortega, L. (2009). Understanding second language acquisition. London: Hodder Education.

Oslo kommune. Utdanningsetaten. (2014). Fremmedspråk 5.-7. årstrinn. Hentet fra http://www.utdanningsetaten.oslo.kommune.no/grunnskole/5-7-trinn/fag-ogferdigheter/fremmedsprak/

Otnes, H. (2007). Følge med og følge opp. Verbalspråklig lyttemarkering i synkrone nettsamtaler. Trondheim: Institutt for språk- og kommunikasjonsstudier, NTNU. Hentet fra http://ntnu.diva-portal.org/smash/get/diva2:122409/FULLTEXT01.pdf

Otnes, H. (2009). Å være digital. I H. Otnes (Red.), $\AA$ være digital i alle fag (s. 11-28). Oslo: Universitetsforlaget.

Penne, S. \& Hertzberg, F. (2008). Muntlige tekster i klasserommet. Oslo: Universitetsforlaget.

Pinter, A. (2006). Teaching young language learners. Oxford: Oxford university press.

Rankin, P. T. (1926). The Measurement of the Ability to Understand Spoken Language. Michigan: University of Michigan.

Rychen, D. S. \& Salganik, L. H. (2003). Key Competencies for a Successful Life and a WellFunctioning Society. Cambridge, MA: Hogrefe \& Huber Pub.

Speitz, H. (2012). Developing a framework for assessing writing in primary school. I A. Hasselgren, I. Drew, \& B. Sørheim (Red.), The Young Language Learner: Researchedbased Insights into Teaching and Learning (s. 11-22). Bergen: Fagbokforlaget.

Speitz, H., Simonsen, T. \& Streitlien, Å. (2007). Evaluering av prosjektet "Forsøk med tidlig start i 2. fremmedspråk", Sluttrapport. Notodden: Telemarksforsking.

St. meld. nr. 23 (2007-2008). (2008). Språk bygger broer: språkstimulering og språkopplæring for barn, unge og voksne. [Oslo]: [Regjeringen]. Hentet fra http://www.regjeringen.no/pages/2077013/PDFS/STM200720080023000DDDPDFS.pdf

St. meld. nr. 30 (2003-2004). (2004). Kultur for læring. Hentet fra http://www.regjeringen.no/Rpub/STM/20032004/030/PDFS/STM200320040030000DDD PDFS.pdf

Svenkerud, S. (2013). «Ikke stå som en slapp potet» - elevsynspunkter på opplæring i muntlige ferdigheter. Acta Didactica Norge, 7(1), 16. Hentet fra http://adno.no/index.php/adno/article/view/273 
Svenkerud, S., Klette, K. \& Hertzberg, F. (2012). Opplæring i muntlige ferdigheter. Nordic Studies in Education, 32(01). Hentet fra http://www.idunn.no/ts/np/2012/01/opplaering_i_muntlige_ferdigheter

Svennevig, J. (2009). Språklig samhandling: Innføring i kommunikasjonsteori og diskursanalyse. Oslo: Landslaget for norskundervisning.

Tyner, K. (1998). Literacy in a digital world: teaching and learning in the age of information. Mahwah, N.J.: Lawrence Erlbaum.

Utdannings- og forskningsdepartementet. (2005). Språk åpner dører: strategi for styrking av fremmedspråk i grunnoppleringen 2005 - 2009. Oslo: Utdannings- og forskningsdepartementet.

Utdanningsdirektoratet. (2006). Lœreplanverket Kunnskapsløftet. Oslo:

Utdanningsdirektoratet. Hentet fra http://www.udir.no/Lareplaner/Kunnskapsloftet/

Utdanningsdirektoratet. (2010). Lcreplan for forsøk med fremmedspråk på barnetrinnet.

Oslo: Utdanningsdirektoratet. Hentet fra

http://webcache.googleusercontent.com/search?q=cache:BmpFfxAo6CYJ:www.udir.no/U pload/larerplaner/fremmedsprak_barnetrinnet/5/lp_forsok_med_fremmedsprak_barnetrin net.doc $+\& \mathrm{~cd}=1 \& \mathrm{hl}=$ no\&ct $=$ clnk\&gl=no\&client $=$ firefox-a

Utdanningsdirektoratet. (2011). Det felles europeiske rammeverket for språk. Lœring, undervisning, vurdering. Oslo: Utdanningsdirektoratet.

Utdanningsdirektoratet. (2012). Rammeverk for grunnleggende ferdigheter. Oslo:

Utdanningsdirektoratet. Hentet fra

http://www.udir.no/Upload/larerplaner/lareplangrupper/RAMMEVERK_grf_2012.pdf?ep

slanguage $=$ no 